\title{
COMPUTER AIDED UTILIZATION OF BACKUP ROLLS*
}

Daniel Hajduk ${ }^{1}$
Pavel Šimeček
Jan Vahalík

\begin{abstract}
Efficiency of back up rolls depends mostly on two parameters - length of campaign and dressing amount after the campaign. The longer the campaign (in terms of rolled tones) is, the higher the dressing amount. To solve this task properly it is necessary to know the distribution of accumulated damage in the working layer of the roll caused by previous campaigns and by loads (separating force and bending) during present campaign respecting changing conditions of material properties (hardness) through radius of the roll. To find an optimum dressing amount an algorithm has been developed and specialized computer program will be presented, that takes real measured loads during the backup roll campaign, calculates fatigue damage in the roll and suggests relevant dressing amount. This can help to prolong service life of rolls, minimize the risk of spalls and reach maximum efficiency in terms of rolled tones $/ \mathrm{km}$ per roll.
\end{abstract}

Keywords: Backup roll; Service life; Dressing amount; Fatigue of rolls.

1 ITA Ltd., Ostrava, Czech Republic.

2 ArcelorMittal Ostrava, Ostrava, Czech Republic.

* Technical contribution to the 51st Rolling Seminar - Processes, Rolled and Coated Products, October $28^{\text {th }}$ to $31^{\text {st }}, 2014$, Foz do Iguaçu, PR, Brazil. 


\section{INTRODUCTION}

Efficiency of utilization of back up rolls depends mostly on the campaign length and subsequent dressing amount. The longer the campaign, the higher should be the dressing amount. But the campaign could not be prolonged too much, because this can cause spalls on the surface of the roll. Very short campaign on the other hand is expensive, because part of the costs of the roll change is constant, independent of the campaign length. Each campaign may be different in terms of loads and generates different degradation of the surface layer of the roll. It makes the situation more complicated. But it is obvious that an optimum must exist for each roll, ensuring lowest cost of the roll per ton/km with acceptably low danger of spalling or other damages.

\section{CONCEPT}

Before solving the optimization task mentioned above (minimum cost) it is necessary to be able to simulate the degradation process of the roll surface layer in dependence of varying parameters during the campaign. Knowing the degradation (called accumulated damage) it is possible to calculate suitable dressing amount to avoid spalls or other damages in the following campaign.

Into the Control System of the mill new models have been implemented (Figure 1):

- Roll stack deflection model Erro! Fonte de referência não encontrada. which calculates distribution of hertz contact pressure between work roll and backup roll generated by each strip during backup roll campaign.

- Roll wear model (present Level 2 model) delivers topical wear profile of both rolls after each strip.

- Model of thermal camber (present Level 2 model) delivers thermal shape of both rolls.

- Cyclic stress model (new model) composes all stresses (contact, bending and resident stresses) and transfers them into cyclic loading.

- Fatigue module Erro! Fonte de referência não encontrada. (new model) calculates for each strip a differential of accumulated damage in surface layer of backup rolls.

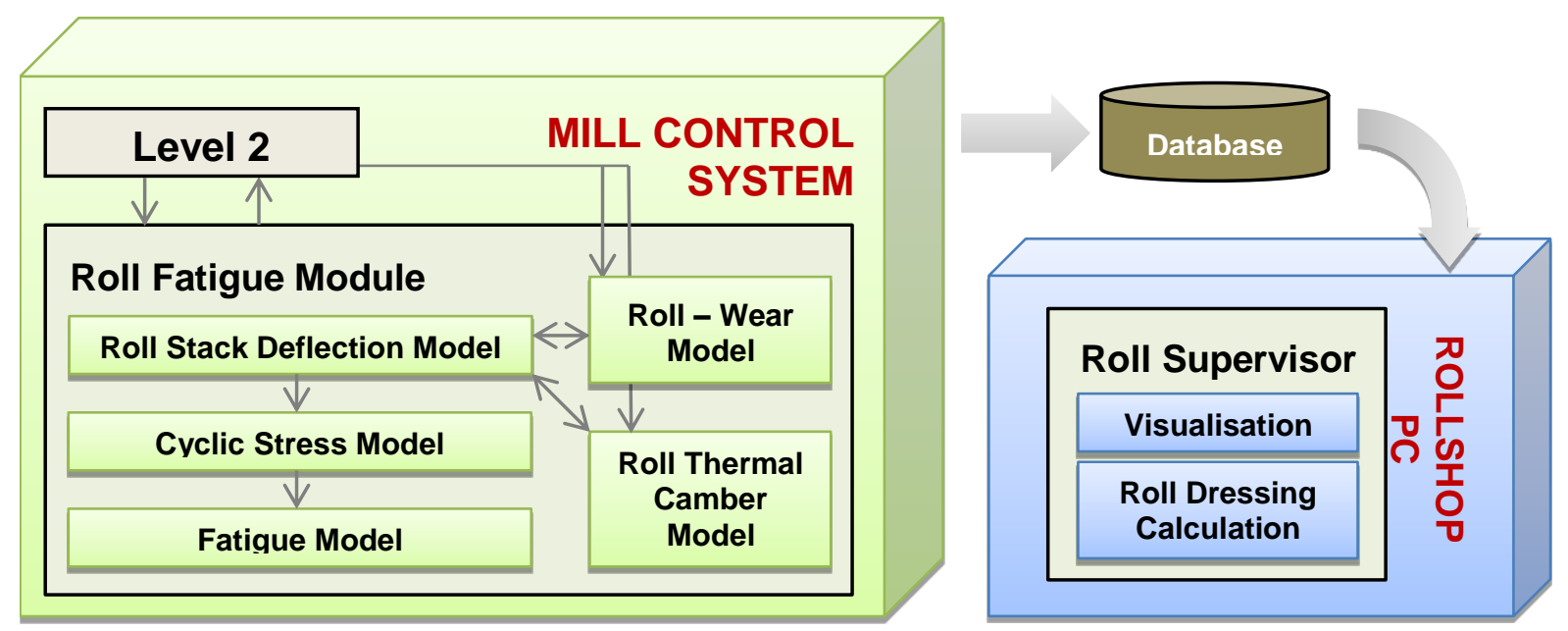

Figure 1. Scheme of models - Modifications of Mill Control System and Roll Supervisor.

* Technical contribution to the 51st Rolling Seminar - Processes, Rolled and Coated Products, October $28^{\text {th }}$ to $31^{\text {st }}, 2014$, Foz do Iguaçu, PR, Brazil. 


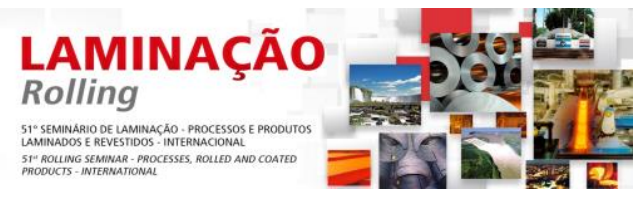

The accumulated damage in the backup rolls is checked after each strip and if it exceeds a pre-set value, the operator (technologist) is informed. Accumulated damage is stored in a database when the backup rolls are changed and sent to Roll Supervisor a module working separately in roll shop on PC.

The Roll Supervisor besides a wide range of visualisations offers calculation of dressing amount according to several criteria.

\section{BACKGROUND THEORY}

\subsection{Contact (Hertzian) Stress}

The contact pressure distribution is calculated for the contact line between backup roll and work roll using simplified spring beam model RollFlex [3]. The rolls are modelled by beams connected by nonlinear springs (Figure 2).

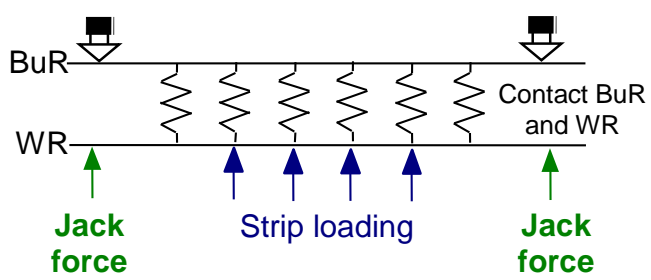

Figure 2. Simplified spring beam model for calculation of Hertz contact load.

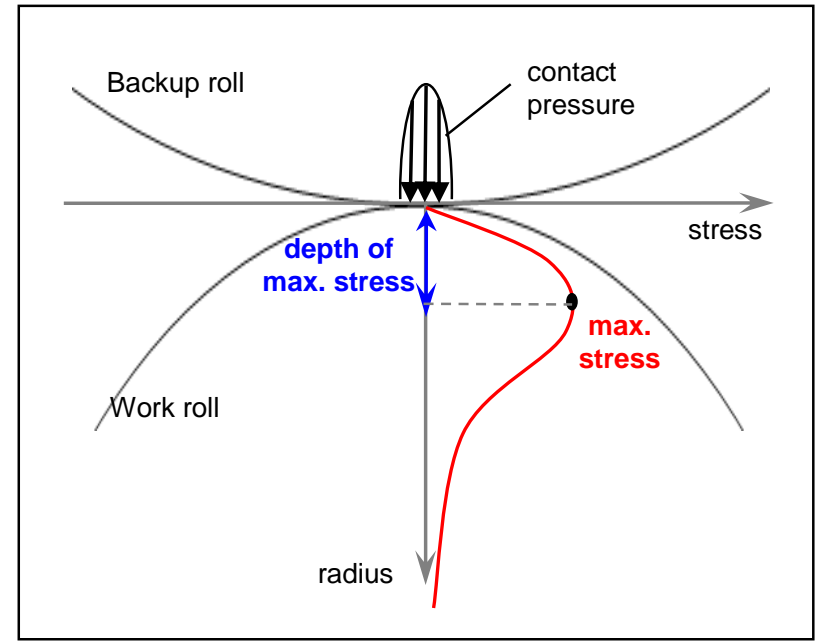

Figure 3. Hertzian stress in rolls.

According to Hertz theory maximum $\mathrm{HMH}$ stress can be found under the surface. The depth of stress peak depends on diameter of the rolls, specific contact force and mechanical properties of roll materials. In common backup rolls for hot strip mills it varies from 3 to $9 \mathrm{~mm}$. In this depth the first microcracks originate and they can growth up to the surface and form spalls [4].

\subsection{Calculation of Accumulated Damage}

The calculation of damaged layer is done according the following scheme (Figure 4):

* Technical contribution to the 51st Rolling Seminar - Processes, Rolled and Coated Products, October $28^{\text {th }}$ to $31^{\text {st }}, 2014$, Foz do Iguaçu, PR, Brazil. 
There are several methods, how the dressing amount can be calculated:

- Based on calculation of accumulated damage (fatigue approach):

Under the assumption that the next campaign generates the same loads resulting in the same differential of accumulated damage as the previous one, we just search for the dressing that will create the same maximum value of accumulated damage as in previous campaign.

- Based on previous grindings (empirical):

This method is based on regression analysis. We know the history of dressings and know the corresponding length of campaigns (tons $/ \mathrm{km}$ ). Supposing dressing amount grows with quadrat of the length of the campaign, it is simple to find coefficient for this relation by e.g. least square method.

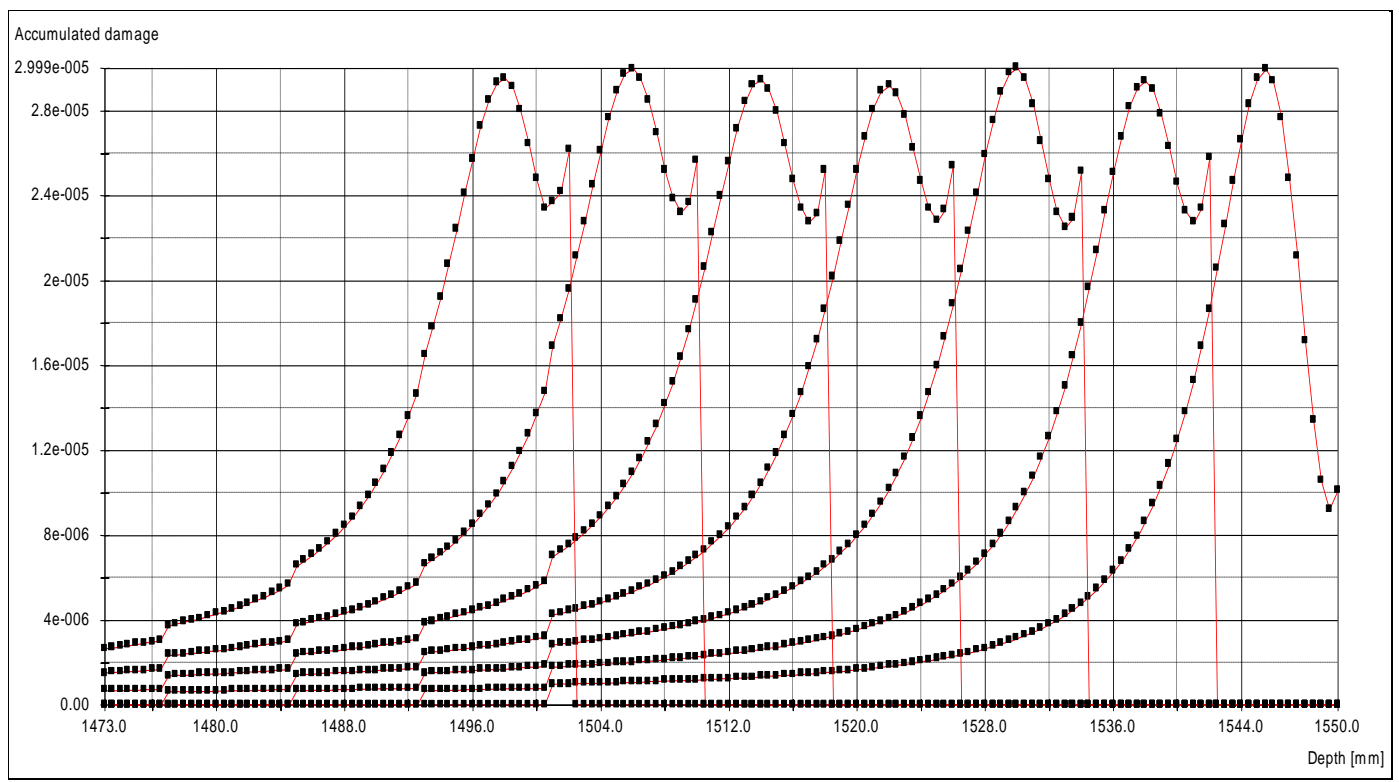

Figure 7. Accumulated damage considering removal of dressing amount

\section{BACKUP ROLL SUPERVISOR}

Backup Roll Supervisor is a database oriented programme, working on PC in roll shop. It keeps all information about particular backup rolls:

- Roll producer,

- Chemical composition,

- Mechanical properties of rolls,

- Data about campaigns (number of campaigns, rolled tons $/ \mathrm{km}$, dressing after campaign, etc.),

- Measured hardness before/after dressing,

- Measured data/damages (Lismar),

- Calculated accumulated damage in rolls,

- Price and other costs of the rolls.

Data is organised in two levels, level of all rolls and level particular roll (Figure 8). Many of the data can be displayed in graphs e.g. tons/c per campaign (Figure 9).

\footnotetext{
* Technical contribution to the 51st Rolling Seminar - Processes, Rolled and Coated Products, October $28^{\text {th }}$ to $31^{\text {st }}, 2014$, Foz do lguaçu, PR, Brazil.
} 


\section{$\underset{\text { Rolling }}{\text { LAMIÇÃO }}$

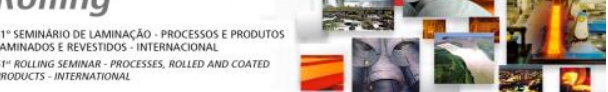

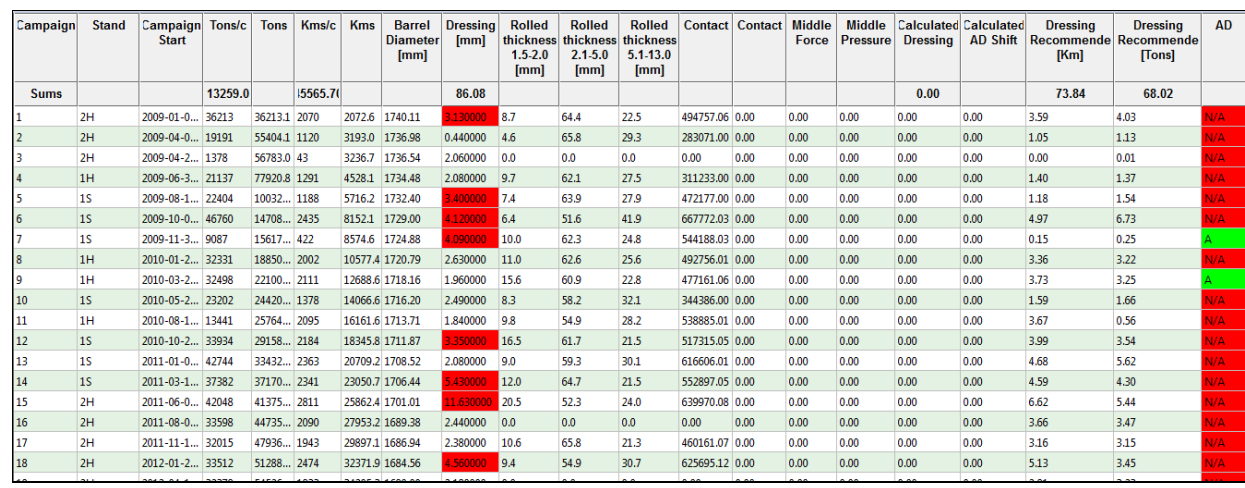

Figure 8. Data of particular roll

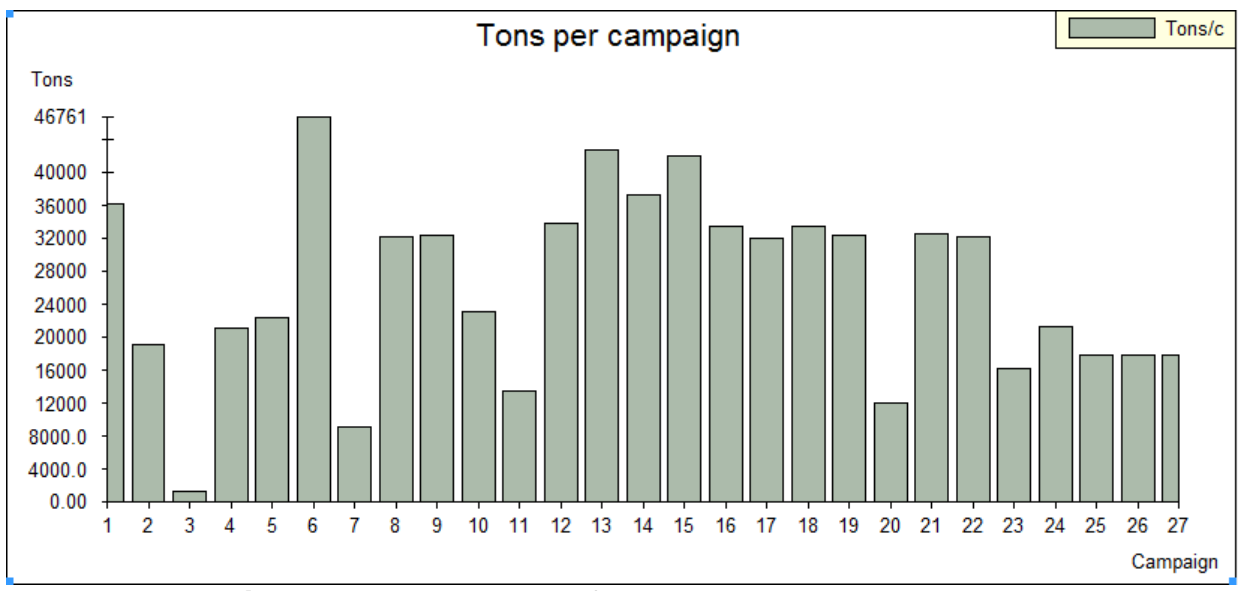

Figure 9. An example of graph - tons per campaign

Very interesting is a distribution of accumulated damage in the roll barrel (Figure 10). Roll surface is 0 and the damage is calculated up to $50 \mathrm{~mm}$ under the surface. There is no concentration near the edges of the roll that means the taper on the rolls are designed properly.

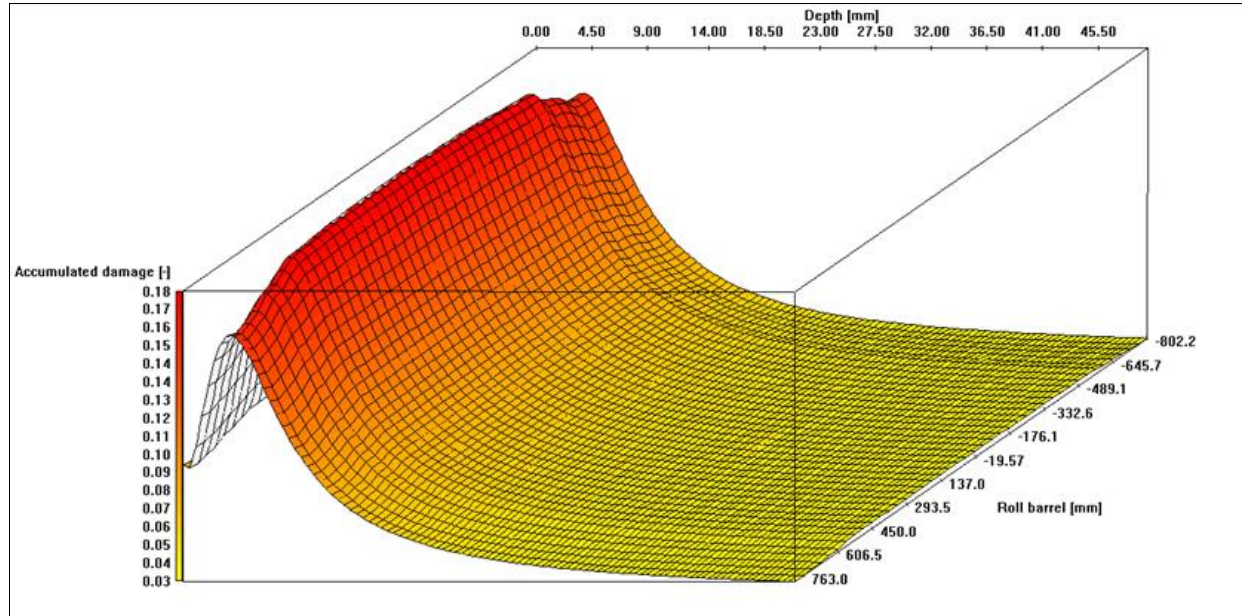

Figure 10. Relative accumulated damage in the roll

Dressing amount versus length of campaign can be displayed for previous campaigns. Using regression, statistical dressing amount can be calculated for each roll, group of rolls or roll producer (Figure 11).

* Technical contribution to the 51st Rolling Seminar - Processes, Rolled and Coated Products, October $28^{\text {th }}$ to $31^{\text {st }}, 2014$, Foz do Iguaçu, PR, Brazil. 


\section{REFERENCES}

1 Decultieux F, Hoffman M, Adams T. Backup Roll Chamfer Design, Profile and Maintenance. Material Science \& Technology; 2004.

2 Hajduk D, Cornelio GT, Bernardes FG. Computer modelling for better BuR performance. Proceedings of conference. 46 Rolling seminar. ABM. Santos, Brazil; 2730 October 2009.

3 ITA Ltd.: Software RollFlex. Online [http://www.ita-tech.cz/en/productsservices/rolling/profile-and-flatness/rollflex-software].

4 Ohkomori Y, Kitagawa I, Shinozuka K, Miyamoto R, Yazaki S, Inoue M. Cause and Prevention of Spalling of Backup Rolls for Hot Strip Mill.

5 ITA Ltd.: Projekt FR-TI3/053: Zlepšení magnetických a užitných vlastností pásů z orientovaných tranformátorových ocelí. Technická zpráva spolupříjemce za rok 2013. (in Czech). Ostrava: ITA Ltd. December 2013. 17 p.

6 Ferfecki P, Fojtík F, Halama R, Hajduk D. Numerické zkoumání vlivu tvaru okrajové části opěrného válce na napjatost a porušování. (in Czech). Hutnické listy. 2010, Nr. 2, LXIII. pp. 72 77. ISSN 0018-8069.

* Technical contribution to the 51st Rolling Seminar - Processes, Rolled and Coated Products, October $28^{\text {th }}$ to $31^{\text {st }}, 2014$, Foz do Iguaçu, PR, Brazil. 